\title{
ANALYSIS OF CHANGES IN EGG QUALITY OF BROILER BREEDERS DURING THE FIRST REPRODUCTION PERIOD
}

\author{
Helena Kontecka, Sebastian Nowaczewski, Marta M. Sierszuła, \\ Katarzyna Witkiewicz \\ Department of Poultry Science, Poznań University of Life Sciences, Witosa 45, 61-693 Poznań, \\ Poland \\ Corresponding author: sebnow@jay.up.poznan.pl
}

\begin{abstract}
In reproductive flocks of poultry it is very important to obtain a large number of eggs with normal structure, optimal morphological composition and interior quality. These elements have very significant influence on the biological value of the egg, which determines normal development of the embryo. The aim of the study was to analyse the physical characteristics, morphological composition and quality of individual components of the eggs of Cobb 500 broiler breeders during the first year of reproduction. The research material was hatching eggs $(280 \mathrm{pcs})$, whose quality was assessed 7 times in the reproductive season at 5-week intervals. The eggs were examined when the hens were aged $26,31,36,41,46,51$ and 56 weeks ( 40 eggs for each age). The following characteristics were evaluated: egg weight (g); egg shape index (\%); egg specific gravity $\left(\mathrm{g} / \mathrm{cm}^{3}\right)$; shell thickness $(\mathrm{mm})$; average number of pores in the eggshell $\left(\mathrm{pcs} / 0.25 \mathrm{~cm}^{2}\right)$; yolk, white and shell weight $(\mathrm{g})$ and their percentage in the egg mass; yolk index (\%) and the number of Haugh units. The investigations proved that as the reproductive season of hens progressed, the weight of their eggs increased. Above all, this was due to the increase in the yolk weight, because its percentage in the egg weight rose with bird age, whereas the percentage of the white decreased. However, as the reproductive season progressed the quality of both the yolk and white deteriorated. No negative relationship between the age of hens and shell quality (weight, thickness) was observed. Only when the birds were aged 56 weeks, the shell thickness was found to be significantly smaller.
\end{abstract}

Key words: broiler breeder, Cobb 500, age, egg characteristics, trend-cycle

In reproductive flocks of poultry it is very important to obtain a large number of eggs with normal structure, optimal morphological composition and interior quality. These elements have very significant influence on the biological value of the egg, which determines normal development of the embryo. As the hens' age increases, the weight of their eggs is usually higher and the shape changes (the eggs become more elongated). On the other hand, Sahin et al. (2009) report the dependence between these characteristics and hatchability results. However, the white characteristics (index, Haugh units) and eggshell traits (weight, thick- 
ness or strength) deteriorate as the reproductive season progresses (Szczerbińska, 1997; Van den Brand et al., 2004; Akyurek and Okur, 2009). A significant role of egg white quality in the embryogenetic process is also reported (Reijrink et al., 2008). Maintaining the normal white viscosity and elasticity may be necessary for sufficient use of ovomucin by the developing embryo during incubation. However, studies show that as the laying season advances, some white characteristics deteriorate (Nowaczewski et al., 2010). Coutts and Wilson (1990) observed successive reduction in the number of Haugh units in hen eggs, on average by 1.5-2 pts per laying month. Similar results were obtained in Japanese quails (Nowaczewski et al., 2010 a). In addition, the yolk index is also related to the strength of the vitelline membrane, which is an equally important component of the hatching egg (Reijrink et al., 2008).

The positive correlation between the number of hatchlings and shell thickness and strength (Dohnal et al., 1986) can be explained by the fact that eggs with a thicker shell are less steam-permeable. This was proved by Arad and Marder (1982), Christensen (1983) and Bennett (1992), who obtained better hatchability in hens and turkeys from eggs with a thicker shell. On the other hand, Yilmaz and Bozkurt (2009) found significant deterioration in the shell characteristics as the age of laying hens increased. The authors observed lower shell thickness, strength and density in hens aged 80 weeks as compared with hens at the peak of lay (aged 28 weeks). Furthermore, the influence of shell quality on hatchability results in Japanese quails was proved by Khurshid et al. (2004). Some researchers also indicate that there is a relationship between hatchability results and egg specific gravity. For example, Dohnal et al. (1989) observed the existence of a significant positive correlation between this characteristic and hatchability. As follows from the findings of Szczerbińska et al. (1996), the value of egg specific gravity decreased significantly with hen age.

Broiler breeders have a genetic inclination to higher feed consumption than laying hens, which often results in their excessive fatness. In consequence, the reproductive indexes, especially the hatchability results, decrease. Therefore, it is important to thoroughly investigate all components of this problem in those birds, together with a detailed analysis of egg quality, including the entire reproductive period. The literature provides the results of several studies concerning the influence of broiler breeder age on egg quality. However, usually the beginning and the end, and possibly the middle of the reproductive period are compared and there is no complex evaluation (Lapao et al., 1999; Tona et al., 2004; Cherian, 2008).

Therefore, the aim of the study was to analyse changes in egg structure, egg morphological composition and quality of yolk, white and shell during the entire period of the first year of reproduction in broiler breeders.

\section{Material and methods}

The experimental material was hatching eggs of Cobb 500 broiler breeders. The birds were kept on bedding in a windowless house with a 15-hour daylight. The 
hens began to lay eggs when they were aged 24 weeks and their mean body weight was about $2 \mathrm{~kg}$. The reproductive period continued until the hens reached 60 weeks of age. During the reproduction the hens were fed with complete diets DJR 1 (from 22 to 40 weeks of age) and DJR 2 (from 40 weeks of age until the end of investigation). The former diet contained $2750 \mathrm{kcal}$ of metabolizable energy, $16.5 \%$ of crude protein and $2.8 \%$ of calcium per kilogram, whereas the latter contained $2730 \mathrm{kcal}$, $16.0 \%$ and $3.0 \%$, respectively.

The quality of randomly selected hatching eggs was assessed 7 times during the reproductive season at five-week intervals. The eggs were tested when the hens were aged 26, 31, 36, 41, 46, 51 and 56 weeks. Forty eggs in each week were selected for the analysis.

The following physical traits of the eggs were evaluated:

- weight $(\mathrm{g})$, with an accuracy of $0.01 \mathrm{~g}$,

- shape index (\%), calculated from the egg width to length ratio,

- specific gravity $\left(\mathrm{g} / \mathrm{cm}^{3}\right)$, using a set for the density determination of solids and liquids.

Besides, the following morphological traits and egg quality characteristics were measured:

- shell weight $(\mathrm{g})$, with an accuracy of $0.01 \mathrm{~g}$, and its percentage,

- shell thickness $(\mathrm{mm})$, with an accuracy of $0.001 \mathrm{~mm}$ by means of a micrometer screw gauge,

- number of pores (per $0.25 \mathrm{~cm}^{2}$ eggshell surface), according to the method developed by Tyler (1953). The equator of the eggshell was chosen for analysis,

- yolk weight $(\mathrm{g})$, with an accuracy of $0.01 \mathrm{~g}$ and its percentage,

- yolk index (\%), which was calculated according to the formula:

Yolk index $=$ yolk height $(\mathrm{mm})$ /yolk width $(\mathrm{mm}) \times 100$,

- white weight $(\mathrm{g})$, calculated by subtraction of the yolk and shell weight from the egg weight, followed by determination of the percentage of egg white.

Haugh units were calculated according to the formula (Williams, 1992):

$$
J H=100 \log \left(H+7.7-1.7 W^{0.37}\right),
$$

where:

$H$ - thick white height, $W$ - egg weight.

Changes in the values of egg quality traits in relation to broiler breeder age were presented in the form of regression equations and were used to plot trait linear trendcycles. In order to clarify the effect of hen age on the values of the analysed traits, linear trends were determined by first degree regression method according to the following model:

where:

$$
y=b 0+b 1 \times 1
$$

$y$ - the phenotypic value of the analysed characteristics, $b 0, b 1$ - partial regression coefficients, $x 1$ - the age of hen. 
In order to determine the influence of bird age on the qualitative characteristics of eggs a one-way analysis of variance (ANOVA) was used. The significance of differences in the mean values of egg characteristics between individual measurement times was verified by Fisher's test. The statistical analysis was made by means of statistical package $\mathrm{SAS}^{\circledR}$ v. 9.1.

\section{Results}

As the hens aged, the weight of their eggs increased significantly, on average by $2.5 \mathrm{~g}$ per 5 weeks preceding consecutive measurements (Figure 1). As far as the egg shape and egg specific gravity are concerned (Figure 2 and 3), significant reductions in the values of those characteristics were observed as the reproductive period progressed. The directional factor of the regression equation (b) for those values was -0.5 and -0.002 , respectively.

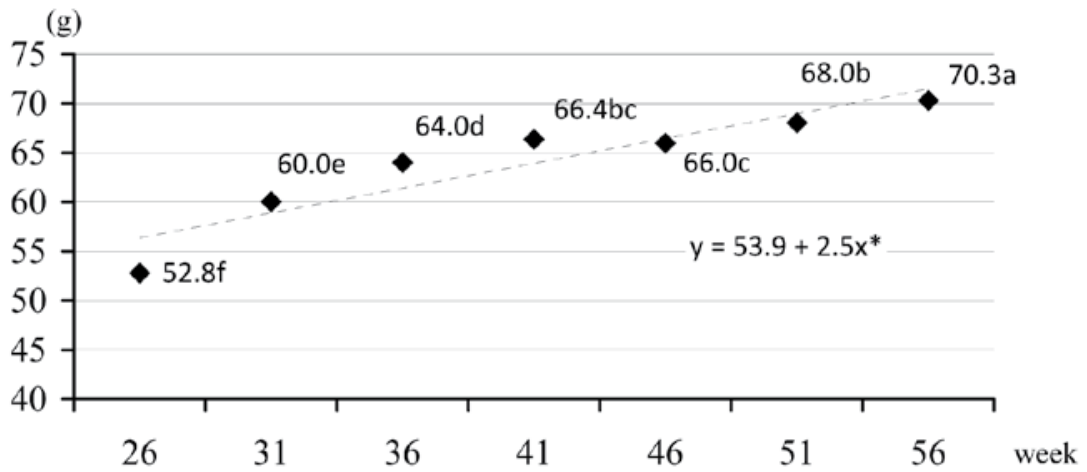

Figure 1. Trend-cycle of egg weight in broiler breeders depending on weeks of age

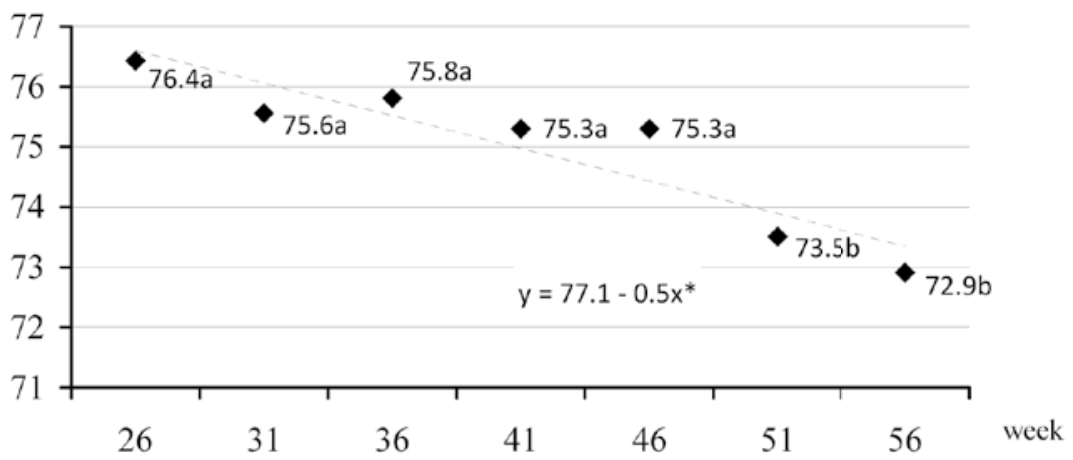

Figure 2. Trend-cycle of egg shape in broiler breeders depending on weeks of age 
In consecutive weeks of hens' age the weights of yolk and white increased significantly by 1.3 and $1.1 \mathrm{~g}$, respectively (Figures 4 and 7). When measuring the other yolk characteristics (Figures 5 and 6), as the reproductive period advanced a significant increase in the percentage of this morphological element in egg weight was observed with a simultaneous significant $(\mathrm{P} \leq 0.05)$ deterioration of yolk quality, as shown by the index. The directional factor value for this characteristic was -1.0 . The significantly negative trend-cycle of the white percentage (Figure 8) indicates a decrease in the value of this trait with advancing reproductive period. Apart from that the significant and negative trend-cycle concerning the white quality (the number of Haugh units) also indicates deterioration of this characteristic with hen age (Figure 9).

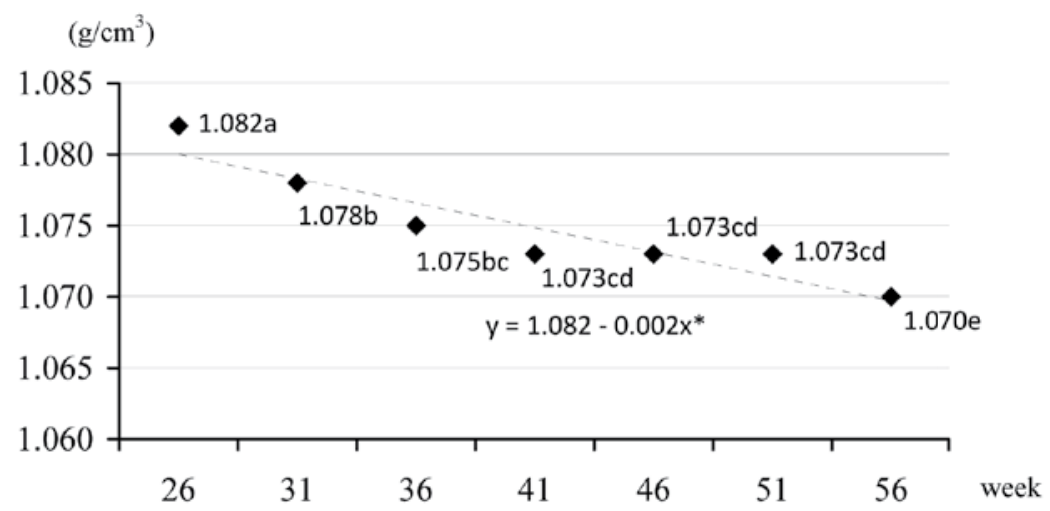

Figure 3. Trend-cycle of egg specific gravity in broiler breeders depending on weeks of age

(g)

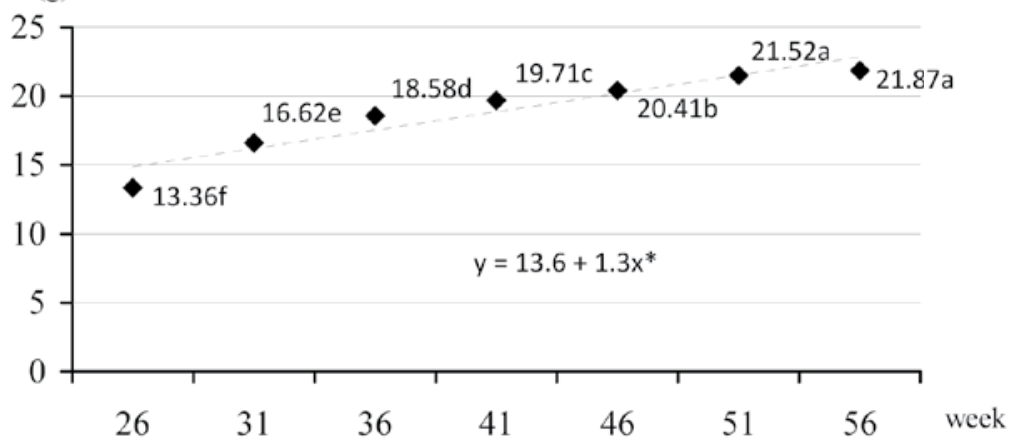

Figure 4. Trend-cycle of yolk weight in broiler breeder eggs depending on weeks of age

As far as the traits describing the shell and its quality are concerned (Figures 10-13), the percentage (Figure 11) of this morphological element in the egg mass was proved to have significantly lower values with increasing hen age $(b=-0.2)$. On the other hand, the shell weight was higher in the 56th than in the 26th week and the difference was $0.58 \mathrm{~g}$ (Figure 10). However, the trend-cycle was not statisti- 
cally significant. Also, no statistically significant reduction in the eggshell thickness was observed as hen age increased, although this characteristic exhibited a negative trend-cycle (Figure 12). The analysis of the results concerning the number of pores in the shell (Figure 13) of the eggs laid in individual periods, the birds' lives did not reveal a statistically significant trend-cycle, where the directional factor was -0.16 .

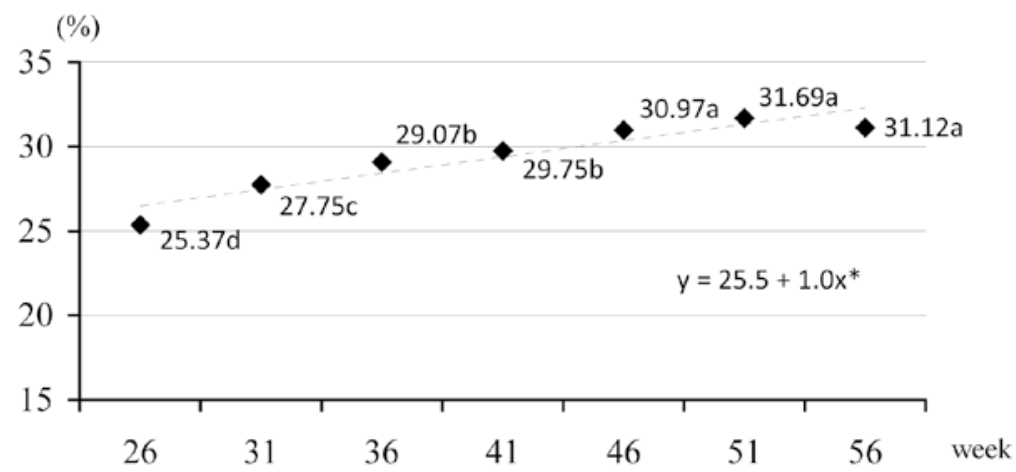

Figure 5. Trend-cycle of yolk content in broiler breeder eggs depending on weeks of age

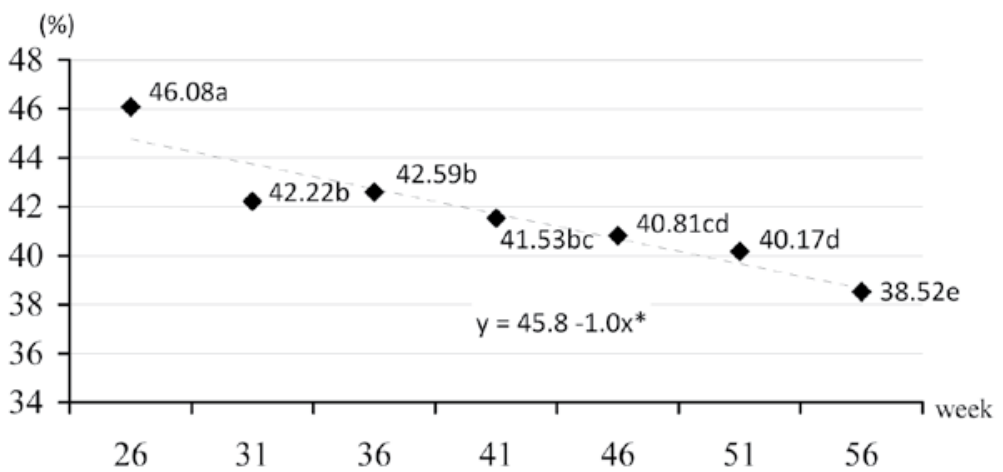

Figure 6. Trend-cycle of yolk index in broiler breeder eggs depending on weeks of age

(g)

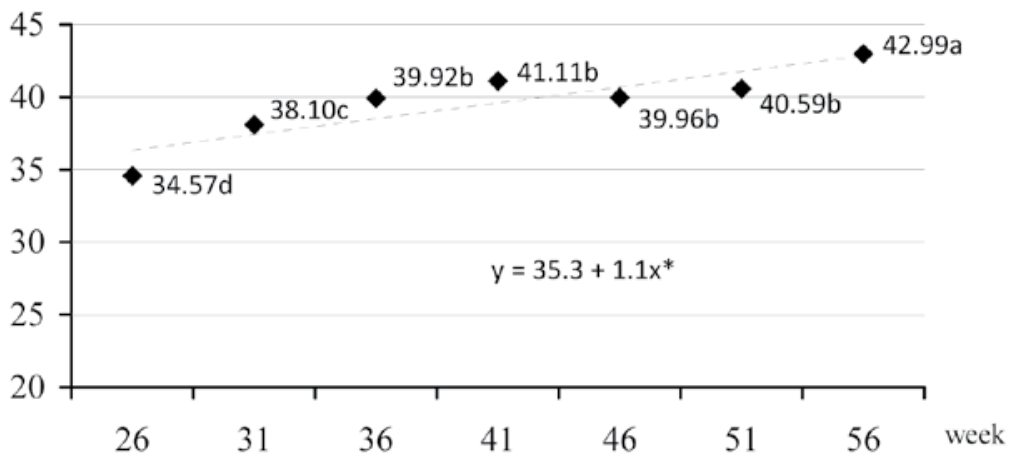

Figure 7. Trend-cycle of white weight in broiler breeder eggs depending on weeks of age 


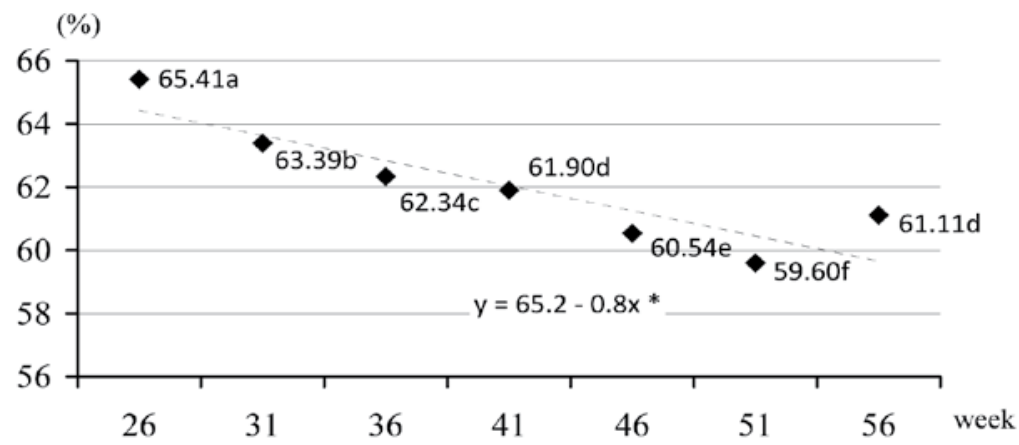

Figure 8. Trend-cycle of white content in broiler breeder eggs depending on weeks of age

(points)

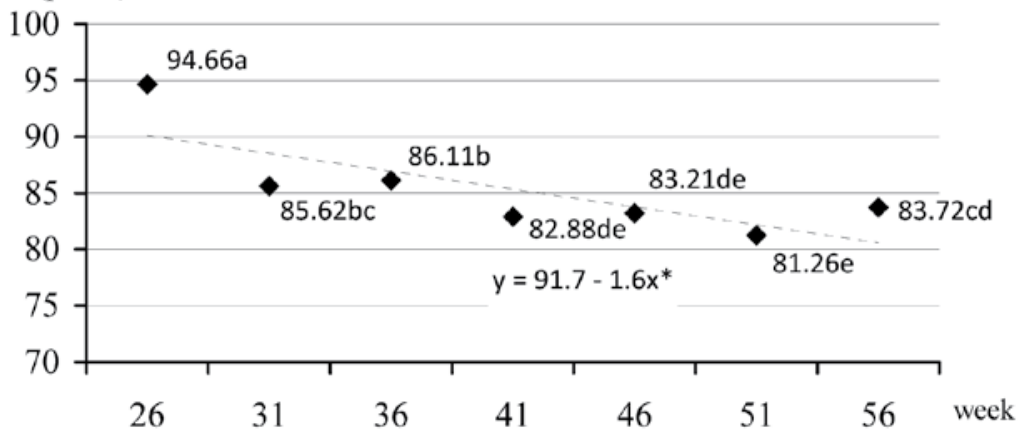

Figure 9. Trend-cycle of Haugh units in broiler breeder eggs depending on weeks of age

(g)

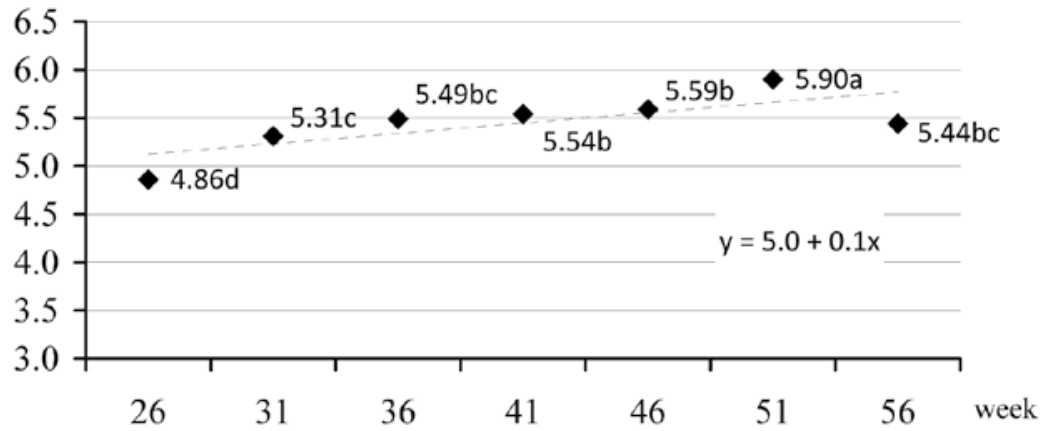

Figure 10. Trend-cycle of eggshell weight in broiler breeder eggs depending on weeks of age 
$(\%)$

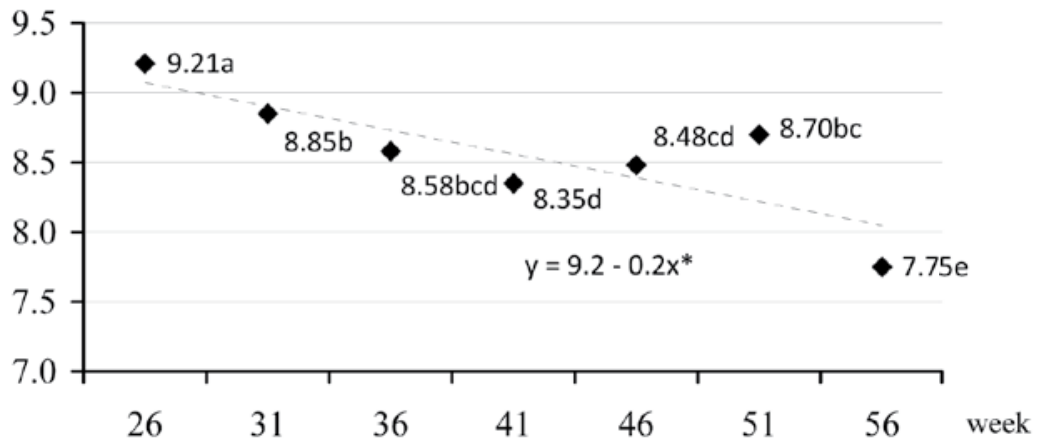

Figure 11. Trend-cycle of eggshell content in broiler breeder eggs depending on weeks of age

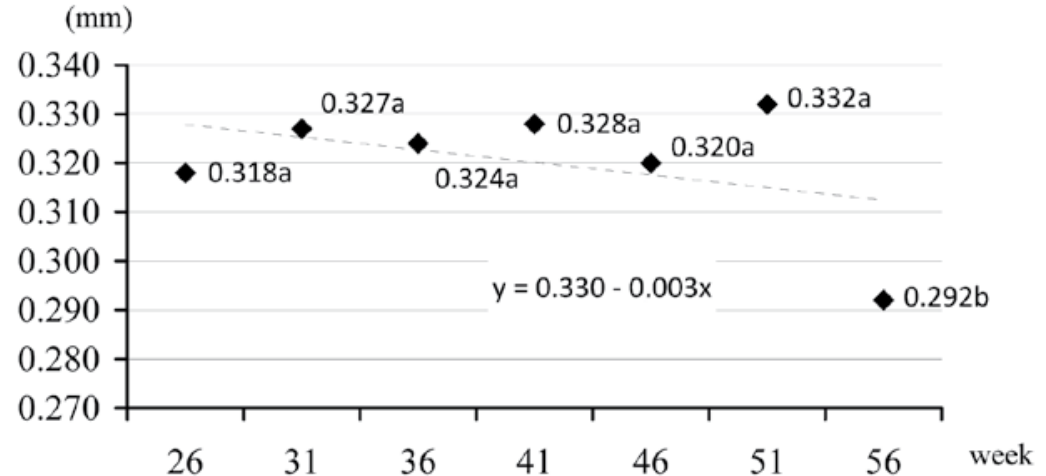

Figure 12. Trend-cycle of eggshell thickness in broiler breeder eggs depending on weeks of age (pcs. $/ 0.25 \mathrm{~m}^{2}$ )

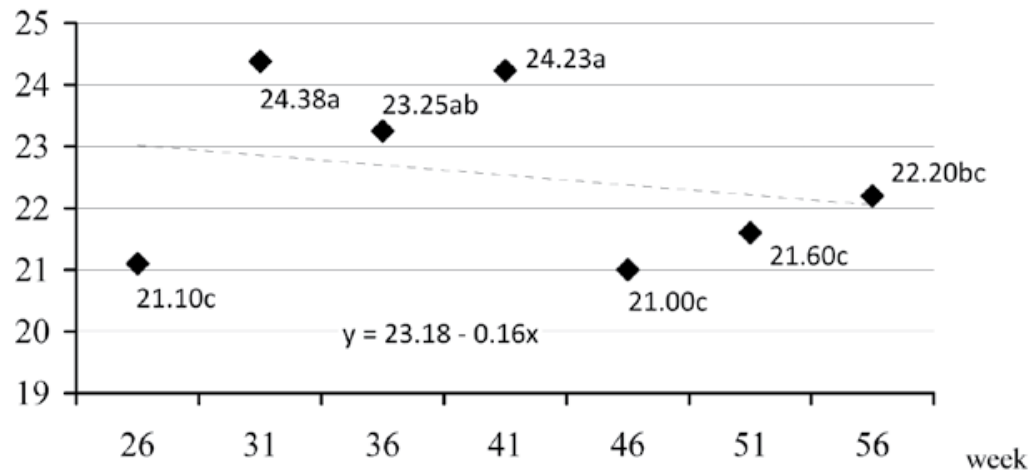

Figure 13. Trend-cycle of number of pores in broiler breeder eggs depending on weeks of age 


\section{Discussion}

Our research proved that the weight of eggs increased with hen age. However, this fact was due to the increasing weight of the yolk rather than white, whose proportion in the egg mass decreased. Tona et al. (2004) observed that the weight of eggs laid by Cobb hens aged 35 and 45 weeks was $66.44 \mathrm{~g}$ and $70.56 \mathrm{~g}$, respectively, and it was higher than in our experiment. On the other hand, Amem and Al-Daraji (2011) also made an experiment on Cobb 500 broiler breeders and proved that the weight of eggs laid by birds aged 51 and 56 weeks was smaller than our results. At both times the difference was about $6.6 \mathrm{~g}$. However, similarly to our experiment, the authors observed a successive increase in egg weight $(\mathrm{P} \leq 0.05)$ as the hens grew older. In Hubbard Flex hens Adamski (2008) found similar tendencies expressed with the trend-cycle. He observed that the mean weight of eggs increased by about $2.5 \mathrm{~g}$ within each three-week interval between consecutive egg quality tests.

As the age of the population of broiler breeders under investigation increased, the egg shape index decreased significantly, i.e. the eggs became more elongated. Adamski (2008) proved a reverse tendency in Hubbard Flex hens. Over 39 weeks of laying the author observed a positive trend-cycle of this characteristic, where the directional factor was 0.16 . On the other hand, some researchers do not provide unequivocal results concerning changes in the egg shape during the reproductive season of other poultry species (González, 1995). However, the egg weight seems to be of key importance, because as it increases, the shape index decreases, i.e. eggs become more elongated (Nowaczewski et al., 2010 b; Kontecka et al., 2011). This fact is also confirmed by the observations of negative coefficients of correlation between those characteristics (Kul and Seker, 2004; Nowaczewski et al., 2008).

The egg specific gravity may be a good indicator of the shell quality. The value of this trait was proved to decrease along with the decrease in the shell thickness (Dohnal et al., 1988; Szczerbińska, 1997). It is related to bird age. Amem and AlDaraji (2011) point to a similar dependence in the eggs of broiler breeders. When the hens were aged 54, 58 and 62 weeks, the values of those characteristics were 1.081 and $375,1.077$ and 344, and $1.060 \mathrm{~g} / \mathrm{cm}^{3}$ and $320 \mu \mathrm{m}$, respectively. Although in our research we found a successive and significant reduction in the egg specific gravity as the reproductive period progressed, we did not observe significant changes in the shell thickness. An exception to the rule was the 56th week when the hens laid eggs with the thinnest shells and lowest specific gravity. These results are confirmed by the findings of Pirsaraei et al. (2011), who compared egg specific gravity in Ross 308 hens aged 22, 34, 48 and 58 weeks. The authors did not observe statistically significant differences and the value of this trait ranged between 1.065 and $1.075 \mathrm{~g} / \mathrm{cm}^{3}$. Probably this fact significantly influences the achievement of good and comparable results of hatchability by those hens during the entire reproductive period. Abudabos (2010) proved that Cobb 500 broiler breeders were characterized by a similar egg weight loss at selected periods of incubation (days 7, 14 and 19) when the eggs were laid by birds aged 26 and 44 weeks. The author compared younger and older birds and did not prove the influence of their age on hatchability from fertilized eggs. 
Pirsaraei et al. (2011) found that eggs from older broiler breeders (aged 58 weeks) were characterized by higher yolk weight and lower white weight, by $1.25 \mathrm{~g}$ on average as compared with birds in the initial period of egg laying (22 weeks of age). Adamski (2008) obtained slightly different results in broiler breeders. For both of the mentioned characteristics he observed a positive trend-cycle, where the directional factor of linear regression was 0.65 and 1.27 , respectively. The reduction in the yolk index value with advancing reproduction may indicate deterioration of its quality. The results of studies on broiler breeders made by Amem and Al-Daraji (2011) also provide unequivocal results. The authors found a higher yolk height value (best yolk quality) in birds aged 58 weeks, as compared with the age of 54 and 62 weeks.

The mean number of Haugh units obtained in our experiment was about 10.2 points higher than that observed by Amem and Al-Daraji (2011) for the same broiler breeders (Cobb 500) of the same age. However, a significant reduction in the value of this trait with bird age was observed $(b=-1.6)$. Tona et al. (2004) and Lapao et al. (1999) proved similar tendencies. They observed successive deterioration of the white quality as the reproductive season of hens progressed.

The literature does not provide many results of studies with age-dependent analyses of changes in the number of pores in the eggshell of broiler breeders. The results obtained in our research are not unequivocal and do not point to the dependence between this characteristic and bird age. The number of pores was proved to be the lowest in the shell of eggs laid at the beginning (26 weeks of age) and at the end (46-56 weeks of age) of the laying period. On the other hand, Peebles and Brake (1987) observed a successive decrease in the value of this characteristic until broiler breeders reached 60 weeks of age. Szczerbińska (1997) noted a decreasing number of pores in the shell of eggs laid by laying hens (Rhode Island Red) only when they were aged between 32 and 44 weeks. According to Tullett (1984), a reduced number of pores in the shell and, as a consequence, limited loss of water from the egg, is a method used by laying hens to adjust to unfavourable climatic conditions. Therefore, it seems that the environmental conditions (temperature and humidity) rather than bird age will strongly influence the number of pores in the eggshell.

The present research proved that as the reproductive season of broiler breeders progressed, the weight of their eggs increased. This fact was mainly due to the increasing yolk weight, because its percentage in the egg mass increased with bird age, whereas the percentage of the white decreased. However, the quality of both the yolk and white deteriorated as the reproductive season advanced. No negative correlation between hen age and shell quality was observed, because its thickness was proved to be significantly lower only when the birds were aged 56 weeks.

\section{References}

A budabos A. (2010). The effect of broiler breeder strain and parent flock age on hatchability and fertile hatchability. Int. J. Poultry Sci., 9: 231-235.

A d a m s k i M. (2008). Relationships between the morphological composition of eggs and the hatchability of chicks of selected bird species (in Polish). Rozprawa 130. Wyd. UTP, Bydgoszcz, 103 pp. 
A k y u re k H., O k u r A.A. (2009). Effect of storage time, temperature and hen age on egg quality in free-range layer hens. J. Anim. Vet. Adv., 8: 1953-1958.

A m e m H.M.M., A 1 - D a raj i J.H. (2011). Zinc improves egg quality in Cobb 500 broiler breeder females. Int. J. Poultry Sci., 10: 471-476.

A ra d Z., M a r d e r J. (1982). Egg-shell water vapour conductance of the domestic fowl: comparison between two breeds and their crosses. Brit. Poultry Sci., 23: 325-328.

B e n n e t t D. (1992). The influence of shell thickness on hatchability in commercial broiler breeder flocks. J. Appl. Poultry Res., 1: 61-65.

C h e ri a n G. (2008). Egg quality and yolk polyunsaturated fatty acid status in relation to broiler breeder hen age and dietary n-3 oils. Poultry Sci., 87: 1131-1137.

$\mathrm{Ch}$ is ten s en V.L. (1983). Distribution of pores on hatching and nonhatching turkey eggs. Poultry Sci., 62: 1312-1316.

Dohnal J.M., Ki ełczewski K., Pospiech M., Łak ota P. (1989). Genetic relationship between egg shell quality and hatchability of eggs from laying hens (in Polish). Zesz. Nauk. Drob., 6: $5-11$.

Dohna l J.M., K ow a ls k a H., K i ełc zew ski K., P o s p i e ch M. (1986). An attempt to estimate the relationships between specific gravity and other quality traits of eggs from five crosses of laying hens (in Polish). Zesz. Nauk. Drob., 3: 5-12.

Dohnal J.M., Pospiech M., Ki ełczewski K., Kowalska H. (1988). Studies on egg specific gravity in flocks of white and brown egg layers (in Polish). Zesz. Nauk. Drob., 5: 67-80.

González M. (1995). Influence of age on physical traits of Japanese quail (Coturnix coturnix japonica) eggs. Ann. Zootech., 44: 307-312.

Khurshid A., Farooq M., Durrani F.R., Sarbiland K., Manzoor A. (2004). Hatching performance of Japanese quails. Livest. Res. Rural. Dev., 16, 2, http://www.lrrd.org/lrrd16/1/ khur161.htm.

Kontecka H., W oźni cka J., Witkiewicz K., N ow a c zew ski S. (2011). Laying, egg and hatchability characteristics in ostrich (Struthio camelus) at different age. Folia Biol., 59: 163-167.

K u l S., S e k e r I. (2004). Phenotypic correlations between some external and internal egg quality traits in the Japanese quail (Coturnix coturnix japonica). J. Poultry Sci., 3: 400-405.

L a p a o C., Ga ma L.T., Chave ir o S o a res M. (1999). Effects of broiler breeder age and length of egg storage on albumen characteristics and hatchability. Poultry Sci., 78: 640-645.

Nowaczewski S., Kontecka H., Rosiński A., Koberling S., Koronowski P. (2010 a). Egg quality of Japanese quail depends on layer age and storage time. Folia Biol. (Kraków), 58: 201-207.

Nowaczewski S., Witkiewicz K., Frątczak M., Kontecka H., Rutkowski A., Krystianiak S., Rosiński A. (2008). Egg quality from domestic and French guinea fowl. Nauka Przyr. Technol., 2: 1-9.

Nowaczewski S., Witkiewicz K., Kontecka H., Krystianiak S., Rosiński A. $(2010$ b). Eggs weight of Japanese quail vs. eggs quality after storage time and hatchability results. Arch. Tierz., 53: 720-731.

P e e ble s E.D., B ra ke J. (1987). Eggshell quality and hatchability in broiler breeder eggs. Poultry Sci., 66: 596-604.

Pirsarae i Z.A., Saki A.A., Kazemi Fard M., S a leh H. (2011). Effect of dietary tallow level on broiler breeder performance and hatching egg characteristics. J. Anim. Vet. Adv., 10: 1287-1291.

Reij rink I.A.M., M e ij e rh of R., Ke m p B., V a n D en B rand H. (2008). The chicken embryo and its micro environment during egg storage and early incubation. World Poultry Sci. J., 64: 581-598.

S ah in E.A., S engor E., Y ardimc i M., Cetingul I.S. (2009). Relationship between pre-incubation egg parameters from old breeder hens, egg hatchability and chick weight. J. Anim. Vet. Adv., 8: 115-119.

S z c z e r b i ń s k a D. (1996). Eggshell quality and hatchability in two breeds of laying hens (in Polish). Zesz. Nauk. AR Szczecin, 169, Zootechnika, 33: 77-85.

S z c z e r b i ń s k a D. (1997). Changes in egg quality in hens from K66 line during year-long reproductive utilization (in Polish). Zesz. Nauk. AR Szczecin, 176, Zootechnika, 34: 109-117. 
Tona K., Onagbesan O., De Ketelaere B., Decuypere E., Bruggeman V. (2004). Effects of age of broiler breeders and egg storage on egg quality, hatchability, chick quality, chick weight, and chick posthatch growth to forty-two days. J. Appl. Poultry Res., 13: 10-18.

T u 11 e t t S.G. (1984). The porosity of avian eggshells. Comp. Biochem. Physiol., 78 A, 1: 5-13.

T y le r C. (1953). Studies on egg shells. II-A Method for marking and counting pores. J. Sci. Food Agric., 4, 266-272.

V an Den Brand H., P arm entie r H.K., K e m p B. (2004). Effects of housing system (outdoor vs cages) and age of laying hens on egg characteristics. Brit. Poultry Sci., 45: 745-752.

W illi a m s K.C. (1992). Some factors affecting albumen quality with particular reference to Haugh unit score. World Poultry Sci. J., 48: 5-16.

Y i $1 \mathrm{maz}$ A.A., B o z kurt Z. (2009). Effects of hen age, storage period and stretch film packaging on internal and external quality traits of table eggs. Lucrări ştiinţifice Zootehnie şi Biotehnologii, 42: $462-469$.

Accepted for printing $10 \mathrm{~V} 2012$

\author{
HELENA KONTECKA, SEBASTIAN NOWACZEWSKI, MARTA M. SIERSZUŁA, \\ KATARZYNA WITKIEWICZ
}

\title{
Analiza zmian jakości jaja kur mięsnych w czasie pierwszego okresu reprodukcji
}

\section{STRESZCZENIE}

W stadach reprodukcyjnych drobiu bardzo ważne jest uzyskanie dużej liczby jaj o prawidłowej budowie, optymalnym składzie morfologicznym i jakości treści. Elementy te wpływają bowiem bardzo istotnie na wartość biologiczną jaja, która determinuje z kolei prawidłowy rozwój w nim zarodka. Celem pracy była analiza zmian cech fizycznych, składu morfologicznego oraz jakości poszczególnych składników jaj kur mięsnych Cobb $500 \mathrm{w}$ pierwszym roku użytkowania reprodukcyjnego. Materiał do badań stanowiły jaja wylęgowe (280 szt.), których ocenę jakości przeprowadzono 7 razy w sezonie reprodukcyjnym, w odstępach 5 tygodniowych. Terminy badania jaj przypadały na 26., 31., 36., 41., 46., 51. i 56. tydzień życia kur. Jednorazowo do badań wybrano 40 jaj. Oceniono następujące cechy jaj: masę $(\mathrm{g})$; indeks kształtu $(\%)$; masę właściwą $\left(\mathrm{g} / \mathrm{cm}^{3}\right)$; grubość skorupy $(\mathrm{mm})$; średnią liczbę porów w skorupie (szt. $\left./ 0,25 \mathrm{~cm}^{2}\right)$; masę żółtka, białka i skorupy (g) oraz ich procentowy udział w masie jaja; indeks żółtka (\%) a także liczbę jednostek Haugha. Przeprowadzone badania wykazały, iż w miarę upływu sezonu reprodukcyjnego kur mięsnych zwiększała się masa znoszonych jaj, co było przede wszystkim wynikiem zwiększającej się masy żółtka, bowiem procentowy jego udział w masie jaja zwiększał się wraz z wiekiem ptaków, a białka malał. Przy czym jednocześnie jakość żółtka jak i białka, w miarę upływu sezonu reprodukcyjnego, pogarszała się. Nie zaobserwowano negatywnej zależności między wiekiem kur a jakością skorupy (masą, grubością), jedynie istotnie mniejszą grubość stwierdzono dopiero w 56. tygodniu życia ptaków. 